\title{
PEMETAAN DAN USULAN JADWAL PENGAMBILAN SAMPAH MENGGUNAKAN METODE VEHICLE ROUTING PROBLEM DENGAN ALGORITMA SWEEP DI PERUMAHAN BUKIT BAMBE
}

\author{
Moh. Bagus Khoirul Prasetyo \\ e-mail : 1903baguskhoirulprasetyo@gmail.com \\ Teknik Industri, Fakultas Teknik \\ Universitas Maarif Hasyim Latif, Sidoarjo, Indonesia
}

\begin{abstract}
ABSTRAK
Sampah adalah bagian yang tidak lepas dari kehidupan manusia modern yang wajib dikendalikan agar tidak menjadi bom waktu di masa depan bagi anak cucu kita. Namun di pinggiran kota masyarakatnya cenderung kurang memperhatikan tentang sampah. Perumahan Bukit Bambe di Driyorejo yang merupakan pinggiran dari kota Gresik juga mengalami hal yang sama, sehingga dalam pemukiman diadakan penanganan sampah dengan cara pengambilan sampah oleh petugas perumahan. . Melihat hal ini, peneliti mencoba membantu dengan melakukan penjadwalan ulang serta memberi masukan atas rute perjalanan petugas. Peneliti mengunakan sistem aplikasi visual dan ditunjang dengan algorithm sweep serta vehicle routing problem untuk menentukan jarak tempuh dan pembuatan rute petugas dalam mengambil sampah Serta dalam usulan penelitian ini dihasilkan juga jadwal pengambilan sampah tiga kali dalam satu minggu.
\end{abstract}

Kata kunci: Sampah, Penjadwalan, Algorithm Sweep

\section{PENDAHULUAN}

Sampah secara terbatas adalah tumpukan bahan yang bekas dan sisa tanaman (daun, sisa sayuran, sisa buangan lain, atau sisa kotoran dari hewan atau benda-benda lain yang dibuang. Dalam pengertian yang luas, sampah diartikan sebagai benda yang dibuang baik dari proses alam ataupun dari hasil proses teknologi (Reksosoebroto, 1990). Pengaruh antara sampah dan kesehatan dapat dikelompokkan langsung dan tak langsung, yang dimaksud langsung adalah efek yang ditimbulkan dari kontak langsung dengan sampah tersebut. Misalnya sifat sampah yang korosif dan karsinogenik. Sampah rumah tangga yang cepat membusuk dapat mengandung kuman pathogen yang menimbulkan penyakit. Sedangkan efek yang tidak langsung, adalah dari pembusukan, pembuangan dan pembakaran sampah itu sendiri (Soemirat, 2000).

Mengacu dari dampak buruk yang ditimbulkan oleh sampah terutama sampah dalam kehidupan sehari hari kita dalam beraktivitas yaitu sampah rumah tangga, peneliti menemukan permasalahan di suatu perumahan yang ada di pinggiran kota Gresik yaitu perumahan Bukit Bambe yang nilai populasi penduduknya diatas 300 jiwa. Bahwa sampah kondisi di perumahan ini cukup sering dikeluhkan oleh warganya karena proses dari sampah itu di buang ditempat sampah sampai diangkut petugas dinilai cukup lama. Dan juga keluhan-keluhan seperti abu bakaran sampah yang berhamburan mengotori beberapa rumah warga yang rumahnya tidak terlalu jauh dari lokasi pembakaran.

Melihat penjadwalan pengambilan sampah yang tidak optimal peneliti menjadikan ini sebagai bahan karya tulis ilmiah di tingkat studi teknik industri sebagai tugas akhir menggunakan vehicle routing problem dengan algoritma sweep. Serta menggunakan aplikasi pemetaan measure map pro dan map ruler.

\section{METODE PENELITIAN}

\section{Vehicle Routing Problem (VRP)}

Vehicle Routing Problem pertama kali diperkenalkan oleh Dantzig dan Ramser, pada tahun 1959 dan semenjak itu telah dipelajari secara luas. Oleh Fisher, VRP didefinisikan sebagai sebuah cara pencarian atas penggunaan yang efisien dari sejumlah kendaraan yang harus melakukan perjalanan untuk mengunjungi sejumlah tempat untuk mengantar dan menjemput orang atau barang. Istilah konsumen menunjukkan pemberhentian untuk mengantar dan menjemput orang/barang. Setiap konsumen harus dilayani oleh satu kendaraan saja. Penentuan pasangan kendaraan-konsumen ini dilakukan dengan mempertimbangkan kapasitas kendaraan dalam satu kali angkut, untuk meminimalkan biaya yang diperlukan. Biasanya penentuan biaya minimal erat kaitannya dengan jarak yang minimal. (Bambang Eko, 2007). VRP sebenarnya merupakan perkembangan atau perluasan dari Travelling Salesman Problem(TSP). TSP dapat dijelaskan 
sebagai suatu masalah dimana seorang salesman harus berangkat dari sebuah depot untuk mengunjungi $\mathrm{n}$ node/kota kemudian kembali ke depot semula dengan memilih feasible tour yang terpendek. Tujuan dari TSP ini adalah mencari biaya per mulasi atau tour minimum dari semua kota sehingga mendapatkan rute dengan lintasan minimum atau meminimumkan biaya. Dengan kata lain mendesain suatu rute perjalanan terpendek dimana setiap node harus dikunjungi oleh salesman tersebut. (Christine, 2003).

\section{Algoritma Clarke \& Wright Savings}

Algoritma Clarke and Wright Savings adalah salah satu algoritma yang dikembangkan untuk permasalahan CVRP dan sering digunakan. Tujuan metode savings yaitu untuk meminimisasi total jarak perjalanan semua kendaraan dan secara tidak langsung untuk meminimisasi jumlah kendaraan yang diperlukan untuk melayani semua tempat perhentian (Clarke G. \& Wright J. W, 1964). Pada tahun 1964, Clarke dan Wright mempublikasikan sebuah algoritma sebagai solusi permasalahan dari berbagai rute kendaraan, yang sering disebut sebagai permasalahan klasik dari rute kendaraan (the classical vehicle routing problem). Algoritma ini didasari pada suatu konsep yang disebut konsep savings.

Algoritma ini dirancang untuk menyelesaikan masalah rute kendaraan dengan karakteristik sebagai berikut. Dari suatu depot barang harus diantarkan kepada pelanggan yang telah memesan. Untuk sarana transportasi dari barang-barang tersebut telah disediakan sejumlah kendaraan, dimana masing-masing kendaraan memiliki kapasitas tertentu sesuai dengan barang yang diangkut. Setiap kendaraan yang digunakan untuk memecahkan permasalahan ini harus menempuh rute yang telah ditentukan, memulai dan mengakhiri di depot, dimana barang-barang diantarkan kepada satu atau lebih pelanggan. Permasalahannya adalah untuk menetapkan alokasi untuk pelanggan diantara rute-rute yang ada, urutan rute yang dapat mengunjungi semua pelanggan dari rute yang ditetapkan dari kendaraan yang dapat melalui semua rute.

Tujuannya adalah untuk menemukan suatu solusi yang meminimalkan total jarak perjalanan kendaraan dan secara tidak langsung juga meminimalkan biaya perjalanan. Solusi ini harus memenuhi batasan bahwa setiap pelanggan dikunjungi sekali dengan permintaan yang diinginkan dan total permintaan pada setiap rute tidak melebihi kapasitas kendaraan yang digunakan. Algoritma Clarke and Wright Savings adalah sebuah algoritma heuristik. Oleh karena itu, algoritma tersebut tidak menghasilkan solusi yang optimal tetapi sering menghasilkan solusi yang baik, yang merupakan suatu solusi yang sedikit berbeda dari solusi optimal.

\section{HASIL DAN PEMBAHASAN}

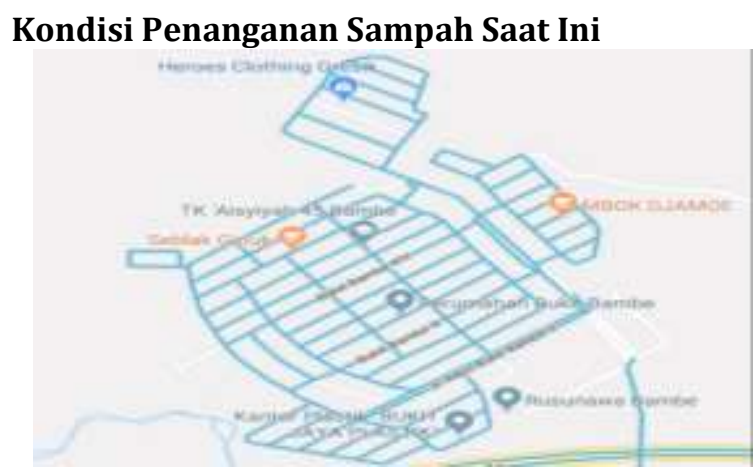

Gambar 1. Denah Perumahan Bukit Bambe

Dari hasil perhitungan luasan wilayah Perumahan Bukit Bambe Driyorejo Gresik ini seluas $335.247 \mathrm{~m} 2$, dari wawancara diketahui setiap petugas bekerja secara terpisah.Petugas membagi wilayah kerja secara bergantian menjadi 2 dengan tujuan agar lebih mudah. Sehingga bila diuraikan dalam tabel adalah sebagai berikut:

Tabel 1. area dan jumlah rumah (titik sampah)

\begin{tabular}{|c|c|c|}
\hline No. & Area & Jumlah rumah \\
\hline 1 & A & 120 rumah \\
\hline 2 & B & 267 rumah \\
\hline 3 & C & 108 rumah \\
\hline 4 & D & 192 rumah \\
\hline 5 & E & 192 rumah \\
\hline 6 & F & 250 rumah \\
\hline 7 & G & 160 rumah \\
\hline 8 & H & 175 rumah \\
\hline \multicolumn{2}{|c|}{ Jumlah } & 1.464 rumah \\
\hline
\end{tabular}

Jumlah keseluruhan adalah 1.464 rumah yang dikerjakan oleh petugas sampah perumahan untuk pengambilan dalam satu waktu. Urutan ini berlaku di setiap hari selama jam kerja dan urutannya berubah secara acak karna bisa jadi dimulai dari titik di kemarin hari yang tidak terjangkau di bloktersebut.

Dari hasil pengumpulan data, sesi wawancara dengan petugas, dan keluhan warga terhadap bau sampah di tempat sampah masing-masing warga karena dinilai lambat dalam pengambilan sampah. Sehingga bisa disebut permasalahan warga tentang sampah karena petugas sampah tidak mampu mengambil semua sampah warga dalam satu kali periode waktu yang sama. 


\section{Perancangan Sistem Baru}

Setiap petugas memiliki wilayah yang berbeda untuk mengambil sampah sebanyak 4 cluster dari yang sebelumnya 8 cluster. Hasil waktu adalah waktu tempuh petugas yang di dapat dari penelitian di lapangan dengan menggunakan alat ukur waktustopwatch. Hari yang dijadwalkan untuk mengambil sampah dalam seminggu adalah hari Selasa, Kamis, dan Minggu. Hasil dari penentuan waktu tempuh di tiap cluster adalah sebagai berikut:

Tabel 2. Waktu Tempuh Rata-Rata Petugas

\begin{tabular}{|c|c|c|c|c|l|}
\hline \multirow{2}{*}{ NO } & \multirow{2}{*}{ Cluster } & \multicolumn{3}{|c|}{ Hari } & $\begin{array}{l}\text { Rata- } \\
\text { rata }\end{array}$ \\
\cline { 3 - 5 } $\mathbf{1}$ & A & 67 & 61 & 62 & $\begin{array}{l}65 \\
\text { menit }\end{array}$ \\
\hline $\mathbf{2}$ & B & 89 & 103 & 97 & $\begin{array}{l}95 \\
\text { menit }\end{array}$ \\
\hline $\mathbf{3}$ & C & 58 & 67 & 61 & $\begin{array}{l}60 \\
\text { menit }\end{array}$ \\
\hline $\mathbf{4}$ & D & 77 & 71 & 84 & $\begin{array}{l}75 \\
\text { menit }\end{array}$ \\
\hline $\mathbf{5}$ & E & 79 & 84 & 67 & $\begin{array}{l}75 \\
\text { menit }\end{array}$ \\
\hline $\mathbf{6}$ & F & 116 & 129 & 132 & $\begin{array}{l}120 \\
\text { menit }\end{array}$ \\
\hline $\mathbf{7}$ & G & 78 & 89 & 84 & $\begin{array}{l}80 \\
\text { menit }\end{array}$ \\
\hline $\mathbf{8}$ & H & 92 & 91 & 82 & $\begin{array}{l}85 \\
\text { menit }\end{array}$ \\
\hline
\end{tabular}

Setelah itu tiap cluster yang ada dikelompokan dengan waktu tempuh yang didapat petugas untuk menghitung jarak tempuh setiap hari yang dilalui dalam satuan kilometer. Sehingga hasil akhir adalah rute tersingkat dengan jarak tempuh yang kecil.

Tabel 3. Jumlah Rumah dan Waktu Tempuh Petugas

\begin{tabular}{|c|r|r|}
\hline Cluster & Jumlah & Waktu tempuh \\
\hline A & 120 unit & 65 menit \\
\hline B & 267 unit & 95 menit \\
\hline C & 108 unit & 60 menit \\
\hline D & 192 unit & 75 menit \\
\hline E & 192 unit & 75 menit \\
\hline F & 250 unit & 120 menit \\
\hline G & 160 unit & 80 menit \\
\hline H & 175 unit & 85 menit \\
\hline
\end{tabular}

Perhitungan jarak dan luasan wilayah pada penelitian ini menggunakan aplikasi pemetaan bernama Measure map PRO untuk menentukan luasan wilayah keseluiruhan maupun luasan wilayah tiap cluster. Menentukan jarak tempuh menggunakan Map Ruler yang mampu memberikan hasil jarak tempuh dalam satuan kilometer. Penentuan waktu menggunakan observasi dilapangan dalam 3 kali pengambilan data menggunakan alat ukurstopwatch seperti yang ada pada tabel diatas. Sehingga hasil dari perhitungan dalam bentuk gambar denagan koordinat maupun jarak kilometer yang tertera.

\section{Hasil Perhitungan Dan Pengukuran}

Perhitungan dari rute baru menghasilkan setiap petugas mengambil sampah masing-masing 4 clusterdengan durasi waktu yang berbeda di tiap cluster disebabkan jumlah rumah berbeda dan jarak tiap cluster ke tempat pembuangan akhir berbeda. Hasilnya, pengambilan sampah yang sebelumnya sulit dilakukan secara menyeluruh karena tidak ada penjadwalan kerja dari lingkungan RT/RW mampu dilakukan dalam 1 periode waktu. Sampah yang mampu diambil secara cepat menurunkan resiko pembusukan sampah yang dekat dengan pemukiman dan menggangu kenyamanan warga.

Tabel 4. Total pembersihan sampah dalam 1 waktu

\begin{tabular}{|c|c|c|c|c|}
\hline No. & Cluster & $\begin{array}{c}\text { Jumlah } \\
\text { (unit) }\end{array}$ & $\begin{array}{c}\text { Jarak } \\
\text { (km) }\end{array}$ & $\begin{array}{c}\text { Waktu } \\
\text { (menit) }\end{array}$ \\
\hline 1 & D & 192 & 2.03 & 75 \\
2 & A & 120 & 1.68 & 65 \\
3 & B & 267 & 2.13 & 95 \\
4 & E & 192 & 1.76 & 75 \\
5 & F & 250 & 2.58 & 120 \\
6 & G & 160 & 2.18 & 80 \\
7 & H & 175 & 2.42 & 80 \\
8 & C & 108 & 1.65 & 60 \\
\hline \multicolumn{2}{|l}{ Jumlah } & 1464 & 16.43 & 650 \\
\hline
\end{tabular}

Dan dari hasil perhitungan ini setiap petugas memiliki hasil kerja mulai dari jarak tempuh, waktu tempuh, dan jumlah titik sampah yang diangkut akan berbeda walau jumlah cluster sama dan hasil perhitungan ini merupakan hasil perhitungan dari data yang didapat dalam 3 hari yang diambil oleh peneliti sebagai berikut:

Tabel 5. Kerja Petugas A

\begin{tabular}{|c|c|c|c|}
\hline \multicolumn{4}{|c|}{ Petugas A } \\
\hline Cluster & $\begin{array}{c}\text { Jumlah } \\
\text { (unit) }\end{array}$ & $\begin{array}{c}\text { Jarak } \\
\text { (km) }\end{array}$ & $\begin{array}{c}\text { Waktu } \\
\text { (menit) }\end{array}$ \\
\hline D & 192 & 2.03 & 75 \\
A & 120 & 1.68 & 65 \\
B & 267 & 2.13 & 95 \\
E & 192 & 1.76 & 75 \\
\hline Jumlah & 771 & 7.6 & 310 \\
\hline
\end{tabular}

Dari tabel kerja petugas A membutuhkan waktu 6 jam 10 menit (310 menit) dalam mengambil sampah di lingkungan perumahan dalam satu kali pekerjaan dengan menempuh total jarak perjalanan adalah 7,6 km. Jika pekerjaan 
dimulai pukul 08.00 pagi akan selesai pada pukul 15.10 sore dengan nilai keterlambatan 20 menit pada 15.30 sore. Sedangkan petugas B membutuhkan waktu 6 jam 40 menit (340 menit) dalam mengambil sampah di lingkungan perumahan dalam satu kali pekerjaan menempuh jarak $8.83 \mathrm{~km}$. Jika pekerjaan dimulai pukul 08.00 pagi akan selesai pukul 15.40 sore dengan nilai keterlambatan 20 menit pada 16.00 sore.

Tabel 6. Kerja Petugas B

\begin{tabular}{|c|c|c|c|}
\hline \multicolumn{4}{|c|}{ Petugas B } \\
\hline Cluster & $\begin{array}{c}\text { Jumlah } \\
\text { (unit) }\end{array}$ & $\begin{array}{c}\text { Jarak } \\
\text { (km) }\end{array}$ & $\begin{array}{c}\text { Waktu } \\
\text { (menit) }\end{array}$ \\
\hline F & 250 & 2.58 & 120 \\
G & 160 & 2.18 & 80 \\
H & 175 & 2.42 & 80 \\
C & 108 & 1.65 & 60 \\
\hline Jumlah & 693 & 8.83 & 340 \\
\hline
\end{tabular}

Kelebihan sistem yang diusulkan oleh peneliti adalah setiap petugas sudah memilik rute tersendiri dan cluster yang dikerjakan terlebih dahulu. Dibandingkan dengan cara kerja yang sebelumya sangat tidak efektif dan efisien. Peneliti sangat berharap usulan ini dapat diaplikasikan dan diterapkan oleh RT/RW setempat. Mengingat sampah juga menjadi masalah paling dasar di tiap aspek lingkungan masyarakat. Terutama di kota besar yang wilayahnya padat pemukiman maupun di pinggiran kota yang kumuh.

\section{Tindak Lanjut Terhadap Sampah Yang Terkumpul}

Sampah yang terkumpul pada perumahan Bukit Bambe hanya dimusnahkan dengan cara dibakar. Hal ini biasanya umum dilakukan pada lingkungan kecil atau mungkin perkampungan, karena minimnya pengetahuan akan nilai ekonomis yang terkandung darisampah.

Perumahan Bukit Bambe, pengolahan sampah hanya dikumpulkan dan dibakar saja, tanpa adanya pengolahan lebih lanjut. Dampak dari pembakaran sampah bagi warga sekitar area tempat pembuangan akhir, rumahnya mudah kotor karena abu sisa pembakaran berterbangan. Melihat situasi yang ada dan bagaimana peran pihak seperti RT/RW terhadap kelanjutan sampahdi perumahan Bukit Bambe menimbulkan saran peneliti untuk menjadikan solusi pengelolaan sampah oleh warga. Dengan cara diadakannya bank sampah atau pengelolaan sampah basah menjadi kompos.

Melihat situasi ini peneliti menambahkan usulan kepada pengurus RT/RW terkait pengelolaan sampah non organik yang memungkinkan masih ada nilai ekonomis bila diolah dengan baik dan benar. Karena dalam nilai positif secara ekonomis bias mendongkrak keuangan bagi desajuga membuka lapangan kerja bagi yang berminat. Di bawah adalah alur chart yang dibuat oleh peneliti dengan tujuan memberikan gambaran kepada warga bahwa sampah bila diolah juga mempunyai sisi positifnya sendiri.

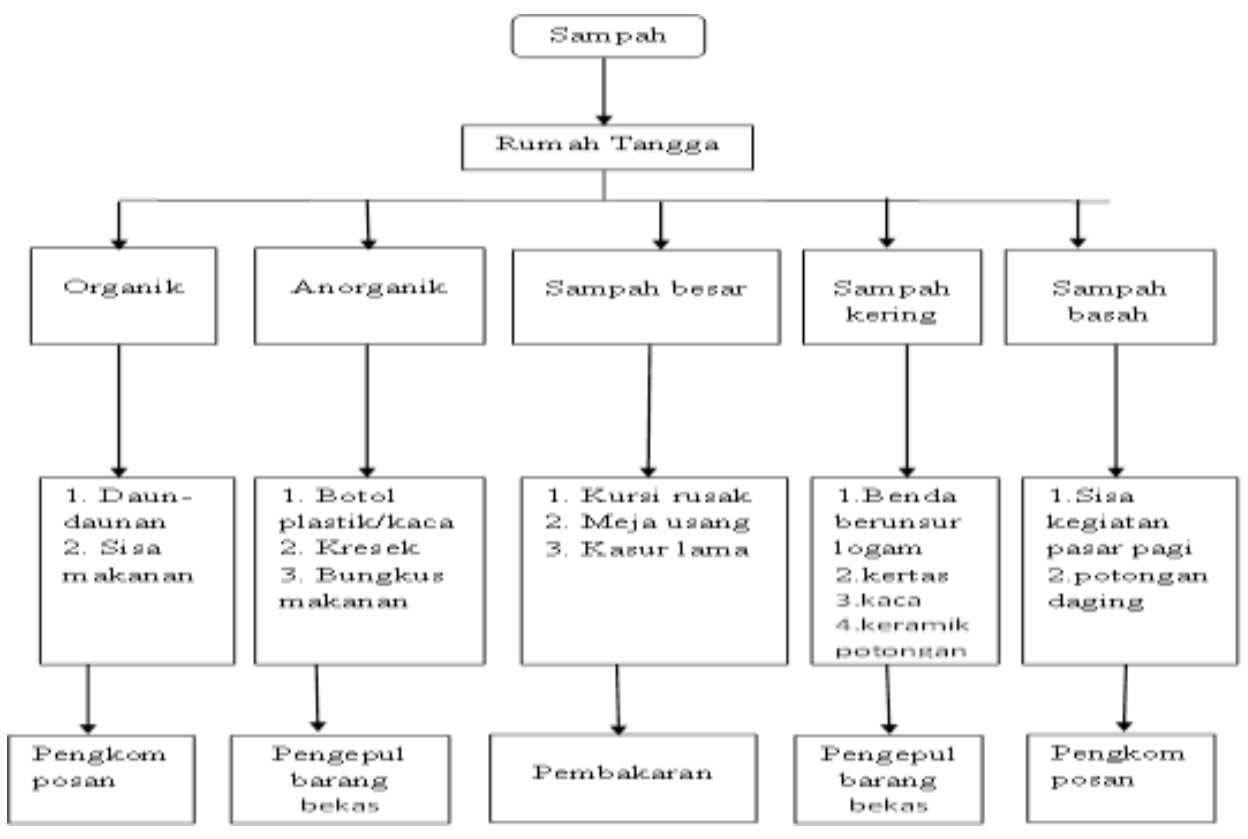

Gambar 2. Flowcharsampahdan akumulasinya 


\section{PENUTUP}

Suatu sistem pekerjaan yang tidak memiliki urutan kerja yang baik akan membuat terganggunya hasil dari pekerjaan tersebut. Baik pekerjaan yang menghasilkan barang ataupun menghasilkan jasa. Seperti yang terdapat di Perumahan Bukit Bambe di Driyorejo Gesik, petugas kebersihan yang bekerja mengambil sampah pada rumah warga tidak memiliki urutan kerja sejak awal, pekerjaannya hanya berdasar pada ingatan dan luangnya waktu setelah membakar sampah di tempat pembuangan sampah Bukit Bambe.

Berdasarkan komplain warga juga tindakan warga yang membuang sampahnya sendiri ke tempat pembuangan akhir, karena tidak segera diambil dan menyebabkan bau, peneliti menggunakan metode Algoritma Sweep untuk menjadikan usulan pengambilan sampah di lingkungan perumahan Bukit Bambe Driyorejo yang lebih efektif dengan pertimbangan waktu dan rute tempuh. Peneliti juga menggunakan tools aplikasi Measure Map PRO dan Map Ruler yang berbasis dengan pemetaan Googgle Maps untuk menghasilkan rute yang baru, waktu tempuh, dan jarak yang dilalui petugas dalam satu kali waktu pengambilan sampah.

Hasilnya, setiap petugas membutuhkan waktu 310 menit dan 340 menit untuk mengangkut sampah di 1464 titik rumah dalam satu periode waktu. Metode pengambilan sampah ini lebih efektif dibandingkan sebelumnya karena tidak ada jadwal yang tetap ditentutan untuk mengambil sampah.

\section{DAFTAR PUSTAKA}

DIANA, A. R., \& Budi Heri Pirngadie, D. P. W. K. (2019). KONTRIBUSI PENGANGKUTAN SAMPAH TERHADAP OPTIMALISASI PENGELOLAAN SAMPAH DI KOTA BANDUNG. Fakultas Teknik Unpas.

Habanono, A. E. D. (2018). OPTIMALISASI JALUR PENGANGKUTAN SAMPAH DI KOTA KUPANG. ITN Malang.

Lasut, A. C., Makalew, F. M., \& Opit, P. F. (2019). ANALISIS RUTE PENGANGKUTAN SAMPAH KOTA MANADO DENGAN PENDEKATAN VEHICLE ROUTING PROBLEM (VRP). Jurnal Ilmiah Realtech, 15(1), 7-12.

Nurcahyo, G. W., Alias, R. A., Shamsuddin, S. M., \& Sap, M. N. M. (2002). Sweep algorithm in vehicle routing problem for public transport. Jurnal Antarabangsa Teknologi Maklumat, 2, 51-64.

Trianto, A. (2018). PENYELESAIAN CAPACITATED VEHICLE ROUTING PROBLEM (CVRP)(Studi Kasus Di PT. Trijaya Abadi Sentausa). University of Muhammadiyah Malang. 